\title{
PHENOLIC COMPOUNDS AND PROPERTIES OF ANTIOXIDANTS IN GRAPEVINE ROOTS (VITIS VINIFERA L.) UNDER LOW-TEMPERATURE STRESS FOLLOWED BY RECOVERY
}

\author{
STANiSŁaW WEIDNER ${ }^{1}$, EdyTa Kordala ${ }^{1}$, WiOLETTA BROSOWSKA-ARENDT ${ }^{1}$,

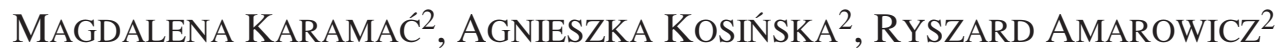 \\ ${ }^{1}$ Department of Biochemistry, \\ Faculty of Biology, University of Warmia and Mazury in Olsztyn \\ M. Oczapowskiego 1A, 10-957 Olsztyn-Kortowo, Poland \\ e-mail: stanislaw.weidner @ uwm.edu.pl \\ ${ }^{2}$ Division of Food Science, \\ Institute of Animal Reproduction and Food Research of Polish Academy of Sciences \\ Tuwima 10, Box 55, 10-718 Olsztyn 5, Poland
}

(Received: May 28, 2009. Accepted: September 7, 2009)

\begin{abstract}
The research has been performed on roots of Vitis vinifera, cv. Himrod, obtained from seedlings grown under chill stress conditions $\left(+10^{\circ} \mathrm{C}\right.$ in the day and $+7^{\circ} \mathrm{C}$ at night), under optimum conditions $\left(+25^{\circ} \mathrm{C}\right.$ in the day and $+18^{\circ} \mathrm{C}$ at night) and from seedling which underwent a recover period after the chill stress treatment. The purpose of the study has been to determine quantitative and qualitative changes in phenolic compounds as well as to demonstrate changes in antiradical properties of extracts from grapevine roots, which appeared as a result of chill stress and during recovery under the optimum conditions following the stress. Phenolic compounds from grapevine roots were extracted using $80 \%$ acetone. The total content of phenolics was determined by colorimetry. The content of tannins was tested by precipitation with bovine serum albumin. The reducing power as well as DPPH ${ }^{*}$ free radical and $\mathrm{ABTS}^{+\bullet}$ cation radical scavenging activity of the extracts were also tested. In order to identify phenolic compounds present in the extracts the RP-HPLC technique was employed. The tested material was found to contain tannins and three identified phenolic acids: ferulic, caffeic and $p$-coumaric ones. The latter occurred in the highest concentrations (from 4.46 to $6.28 \mu \mathrm{g} / \mathrm{g}$ fresh matter). Ferulic acid appeared in smaller amounts (from 1.68 to $2.65 \mu \mathrm{g} / \mathrm{g}$ fresh matter), followed by caffeic acid (from 0.87 to $1.55 \mu \mathrm{g} / \mathrm{g}$ fresh matter). Significantly less total phenolic compounds occurred in roots of seedlings subjected to chill stress. However, the total content of these compounds increased significantly in roots of plants which underwent recovery after chill stress. Concentration of tannins was determined by two methods. The content of condensed tannins was depressed in roots as a result of low temperature stress, whereas the content of condensed and hydrolysing tannins (determined via the BSA method) rose under chill stress conditions. A significant increase in tannins in root extracts (determined with both methods) was found during the recovery process after the stress. The three identified phenolic acids appeared in grapevine roots as ester-bound compounds. It has been demonstrated that the content of phenolic acids significantly fell as a result of low temperatures, but increased during recovery after chill stress. The weakest ability to scavenge $\mathrm{DPPH}^{\bullet}$ and $\mathrm{ABTS}^{+\bullet}$ free radicals as well as the reducing power were shown by the extract obtained from grapevine roots from the seedlings subjected to chill stress. Both free radical scavenging activity and reducing power were observed to increase considerably during recovery after stress. This seems to prove that during the recovery process following chill stress the synthesis of antioxidative compounds in grapevine roots is much more intensive.
\end{abstract}

KEY WORDS: antioxidant system, oxidative stress, chill stress, grapevine roots, phenolic compounds.

\section{INTRODUCTION}

Good growth and development of plants depends on suitable environmental conditions. Air humidity, soil moisture, external temperature, light intensity and chemical composition of the substratum are particularly important in this respect. In nature, environmental conditions change constantly and once they exceed threshold values, they turn into stress factors.

There are various defence mechanisms employed by plants to combat abiotic stresses, but they are enable plants to adapt to unfavourable environmental conditions. Chil- 
ling has an immediate effect on membrane fluidity and enzyme kinetics, thereby influencing many cellular processes (Levitt 1980; Guy 1990).

Abiotic stress factors such as shortage of water, extremely high or low temperatures or excessive salinity cause similar effects to those resulting from tissue damage or secondary stresses like osmotic or oxidative stress (Kmieć et al. 2005). Antioxidants can prevent or delay the oxidation process caused by free radicals (FR) and reactive oxygen species (ROS) in biological systems (Bartosz 1997). Plant phenolics, including phenolic acids, are widespread secondary metabolites, which have been shown to give defence against oxidative stress from endogenous ROS and FR (Choi et al. 2006; Kim and Chung 2002).

The aim of the study has been to investigate the quantitative and qualitative modifications of phenolic compounds and to study the antioxidative activity and the reducing power of extracts of grapevine roots, which occur under the low-temperature stress and following recovery.

\section{MATERIAL AND METHODS}

\section{Plants}

The material for the study consisted of whole root systems of grapevine Vitis vinifera, cultivar Himrod. The seedlings from which the roots were obtained had been purchased from a plant nursery in Jabłonowo (Poland).

\section{Plant growth conditions}

Grapevine seedlings (in 2-litre pots) were placed in FITOTRON plant growth chambers made by Snijders Scientific, Tiburg-Holland, model Economic-deluxe 04.1, in which the proper experiment was conducted after two weeks during which the plants were acclimatised under conditions which were optimum for the growth and development of grapevine. During the acclimatisation of plants to the conditions in the growth chambers as well as throughout the whole experiment, soil moisture was maintained at an optimum level, i.e. 70\%. To monitor soil moisture, a Moisture Meter made by Mera, model VP-PRL-Nr 279462, was used. The conditions of the experiment are specified in Table 1.

One of the growth chambers provided grapevine seedlings with optimum growth conditions $\left(+25^{\circ} \mathrm{C}\right.$ in the day and $+18^{\circ} \mathrm{C}$ at night), whereas the other was programmed to chill stress conditions $\left(+10^{\circ} \mathrm{C}\right.$ daytime and $+7^{\circ} \mathrm{C}$ at night $)$.
Seedlings kept in the chamber with optimum conditions for the growth of grapevine $\left(+25^{\circ} \mathrm{C}\right.$ in the day and $+18^{\circ} \mathrm{C}$ at night) were marked as Control 1 (C1). Plants which were kept for a week under chill stress conditions $\left(+10^{\circ} \mathrm{C}\right.$ in the day and $+7^{\circ} \mathrm{C}$ at night) were designated as S. Grapevine seedlings which stayed for two weeks in the growth chamber, which had the optimum plant growth conditions $\left(+25^{\circ} \mathrm{C}\right.$ in the day and $+7^{\circ} \mathrm{C}$ at night), were named Control 2 (C2). Finally, seedlings which remained for a week under chill stress conditions $\left(+10^{\circ} \mathrm{C}\right.$ in the day and $+7^{\circ} \mathrm{C}$ at night $)$ and for the following week were transferred to optimum growth conditions $\left(+25^{\circ} \mathrm{C}\right.$ in the day and $+18^{\circ} \mathrm{C}$ at night $)$ were assigned the symbol $\mathrm{S}+\mathrm{R}-$ a trial consisting of chill stress and recovery after the stress.

The whole experiment lasted for two weeks, and after a pre-defined incubation period in the growth chambers, whole roots systems were incised from grapevine seedlings. Prior to this treatment, soil was removed from roots by rinsing with water. Carefully cleaned and surface dried roots were frozen in liquid nitrogen, lyophilised and fragmented in an impact grinder.

Dry matter of roots was determined having first obtained constant mass of the plant material dried at $+80^{\circ} \mathrm{C}$ for 48 hours (AOAC, 1990).

\section{Extraction of phenolic compounds}

Phenolic compounds were extracted from roots three times into $80(\mathrm{w} / \mathrm{v})$ acetone for $15 \mathrm{~min}$ at $80^{\circ} \mathrm{C}$, as described by Amarowicz et al. (1995). After evaporating the organic solvent in a rotary evaporator at $45^{\circ} \mathrm{C}$, the remaining aqueous solution was lyophilized.

\section{Determination of total phenolics}

The content of total phenolic compounds in the extracts was determined using the Folin-Ciocalteau's reagent (Naczk and Shahidi 1989) and (+)-catechin was used as a standard.

\section{Separation and analysis of phenolic acids by HPLC}

Phenolic acids (free and those liberated from soluble esters and from soluble glycosides) were isolated from the extracts according to the method previously described by Krygier et al. (1982), Zadernowski and Kozłowska (1983), and Weidner et al. (2000). An aqueous suspension of the methanolic extract $(200 \mathrm{mg}$ in $20 \mathrm{ml}$ ) was adjusted to $\mathrm{pH} 2$ with $6 \mathrm{M} \mathrm{HCl}$, and free phenolic acids were extracted five times into $20 \mathrm{ml}$ diethyl ether using a separatory funnel. The ether extract was evaporated to dryness under vacuum

TABLE 1. Experiment conditions.

\begin{tabular}{|c|c|c|c|c|c|}
\hline Sample & Time of experiment & $\begin{array}{c}\text { Temperature } \\
\text { of day }\end{array}$ & $\begin{array}{c}\text { Temperature } \\
\text { of night }\end{array}$ & Light/dark & Intensity of light \\
\hline $\begin{array}{l}\text { Control } 1 \\
\text { (C1) }\end{array}$ & 1 week under optimum conditions & $+25^{\circ} \mathrm{C}$ & $+18^{\circ} \mathrm{C}$ & $16 \mathrm{~h} / 8 \mathrm{~h}$ & $84 \mu \mathrm{mol} \times \mathrm{m}^{-2} \times \mathrm{s}^{-1}$ \\
\hline $\begin{array}{l}\text { Stress of low temperature } \\
\text { (S) }\end{array}$ & 1 week under stress conditions & $+10^{\circ} \mathrm{C}$ & $+7^{\circ} \mathrm{C}$ & $16 \mathrm{~h} / 8 \mathrm{~h}$ & $84 \mu \mathrm{mol} \times \mathrm{m}^{-2} \times \mathrm{s}^{-1}$ \\
\hline $\begin{array}{l}\text { Control } 2 \\
\text { (C2) }\end{array}$ & 2 weeks under optimum conditions & $+25^{\circ} \mathrm{C}$ & $+18^{\circ} \mathrm{C}$ & $16 \mathrm{~h} / 8 \mathrm{~h}$ & $84 \mu \mathrm{mol} \times \mathrm{m}^{-2} \times \mathrm{s}^{-1}$ \\
\hline \multirow{2}{*}{$\begin{array}{l}\text { Recovery } \\
(\mathrm{S}+\mathrm{R})\end{array}$} & 1 week under stress conditions & $+10^{\circ} \mathrm{C}$ & $+7^{\circ} \mathrm{C}$ & $16 \mathrm{~h} / 8 \mathrm{~h}$ & $84 \mu \mathrm{mol} \times \mathrm{m}^{-2} \times \mathrm{s}^{-1}$ \\
\hline & 1 week under optimum conditions & $+25^{\circ} \mathrm{C}$ & $+18^{\circ} \mathrm{C}$ & $16 \mathrm{~h} / 8 \mathrm{~h}$ & $84 \mu \mathrm{mol} \times \mathrm{m}^{-2} \times \mathrm{s}^{-1}$ \\
\hline
\end{tabular}


at room temperature. The water solution was neutralized and then lyophilized. The residue was dissolved in $20 \mathrm{ml}$ of $2 \mathrm{M} \mathrm{NaOH}$ and hydrolysed for $4 \mathrm{~h}$ under a nitrogen atmosphere at room temperature. After acidification to $\mathrm{pH} 2$ using $6 \mathrm{M} \mathrm{HCl}$, phenolic acids released from soluble esters were extracted from the hydrolysate five times into $30 \mathrm{ml}$ diethyl ether. Nine $\mathrm{ml}$ of $6 \mathrm{M} \mathrm{HCl}$ were added to the water solution, which was then placed in nitrogen atmosphere and hydrolysed for $1 \mathrm{~h}$ in a boiling water bath. Phenolic acids released from soluble glycosides were separated from the hydrolysate five times into $45 \mathrm{ml}$ diethyl ether. After ether evaporation, the dry residue was dissolved in $2 \mathrm{ml}$ methanol and filtered through a $0.45 \mu$ m nylon filter. The sample was injected onto an HPLC column. A Shimadzu HPLC system was employed: LC - 10 ADVP pump, photodiode array detector UV-VIS SPD - M10AVP, oven CTO - 10 ASVP, Controller SCL - 10AVP. The conditions of the separations were as follows: pre-packed LUNA $\mathrm{C}_{18}$ column (5 $\mu \mathrm{m}, 4.6 \times 250 \mathrm{~mm}$; Phenomenex); mobile phase water-acetonitrile - acetic acid (88:10:2, v/v/v) (Amarowicz and Weidner 2001); flow rate of $1 \mathrm{ml} \cdot \mathrm{min}^{-1}$; injection volume of $20 \mu \mathrm{l}$; the detector was set at 280 and $320 \mathrm{~nm}$; oven temperature was $20^{\circ} \mathrm{C}$.

\section{Determination of tannins with the vanillin method}

The content of tannins in the extract was determined using the modified Vanillin Assay (Price et al. 1978). Results were expressed as absorbance units at $500 \mathrm{~nm}$ per $\mathrm{mg}$ of extract $\left(\mathrm{A}_{500} / \mathrm{mg}\right)$. Briefly, to $0.5 \mathrm{ml}$ of extract, $2.5 \mathrm{ml}$ of solution B (obtained by dissolving $0.5 \mathrm{~g}$ of vanillin in 100 $\mathrm{ml}$ of solution A) was added. Solution A was made by adjusting $4 \mathrm{ml}$ of concentrated $\mathrm{HCl}$ to $100 \mathrm{ml}$ with methanol. The samples were left in the dark at room temperature for $20 \mathrm{~min}$, and then absorbance was measured at $500 \mathrm{~nm}$.

\section{Determination}

of tannins using the protein precipitation method

The content of tannins in the extract was determined using the method described by Hagerman and Butler (1978). Briefly, $2 \mathrm{ml}$ of bovine serum albumin (BSA) solution (concentration $1 \mathrm{mg} \cdot \mathrm{ml}^{-1}$ in $0.2 \mathrm{M}$ acetate buffer at $\mathrm{pH}$ 5.5 containing $0.17 \mathrm{M} \mathrm{NaCl}$ ) was added to $1 \mathrm{ml}$ of the extract. The sample was left for $15 \mathrm{~min}$ at room temperature and then centrifuged $(5000 \times \mathrm{g})$. After $15 \mathrm{~min}$ of centrifugation, the supernatant was removed and the pellet was washed with $1 \mathrm{ml}$ acetate buffer and centrifuged again $(5000 \times \mathrm{g} / 15 \mathrm{~min})$. The sediment was dissolved in $4 \mathrm{ml}$ of solution containing: $1 \% \mathrm{SDS}$ and $5 \% \mathrm{TEA}$, and $1 \mathrm{ml}$ of $0.01 \mathrm{M} \mathrm{FeCl}_{3}$ in $0.01 \mathrm{M} \mathrm{HCl}$ was added. The samples were left for $30 \mathrm{~min}$ at room temperature and the absorbance was measured at $510 \mathrm{~nm}$. The results were expressed as absorbance units at $510 \mathrm{~nm}$ per $1 \mathrm{mg}$ of extract $\left(\mathrm{A}_{510} / \mathrm{mg}\right)$.

\section{Antiradical activity of roots extracts}

The antiradical activity was analyzed with the method described by Yen and Chien (1995). Briefly, 0.01-0.04 mg of lyophilized extract dissolved in $0.1 \mathrm{ml}$ of methanol was added to $2 \mathrm{ml}$ of methanol; then, $0.25 \mathrm{ml}$ of a $\mathrm{DPPH}^{\bullet}(2,2$ diphenyl-1-picrylhydrazyl) solution in the concentration of $1 \mathrm{mg} \cdot \mathrm{ml}^{-1}$ methanol was added. The mixture was left in the dark at room temperature for $20 \mathrm{~min}$. After that time, absorbance was read at a wavelength of $517 \mathrm{~mm}$. The analysis was performed in three replications.

\section{Total Antioxidant Activity (TAA)}

The Total Antioxidant Activity of the extracts was determined according to the Trolox equivalent antioxidant activity (TEAC) assay described by Re et al. (1999). TAA was expressed as mmol Trolox equivalent/g of extract.

\section{Reducing power of extracts}

Reducing power of phenolics present in the extracts was determined using the method described by Yen and Chen (1995). Briefly, $1 \mathrm{ml}$ of water containing 0.2-1.0 $\mathrm{mg}$ of an extract was pipetted into a tube. Next, $2.5 \mathrm{ml}$ of $0.2 \mathrm{M}$ phosphate buffer, $\mathrm{pH} 6.6$, and $2.5 \mathrm{ml}$ of $1 \%$ solution of potassium ferrocyanide were added. The mixture was incubated in a water bath at $50^{\circ} \mathrm{C}$ for $20 \mathrm{~min}$. Afterwards, $2.5 \mathrm{ml}$ of $10 \%$ TCA (trichloroacetic acid) solution was added. To 2.5 $\mathrm{ml}$ of this sample, $2.5 \mathrm{ml}$ of $0.1 \% \mathrm{FeCl}_{3}$ in distilled water were added. After $10 \mathrm{~min}$ absorbance was measured at a wavelength of $700 \mathrm{~nm}$. The analysis was performed in three replications, and means for the values thus obtained were derived.

\section{Statistical evaluation}

All experiments were repeated four times, with three replications for each sample. The presented values are the means of twelve determinations \pm SD. Statistically significant differences in the mean values were tested by Student's $t$-test.

\section{RESULTS}

\section{Dry matter content}

The results prove that dry matter in roots of grapevine seedlings subjected to chill stress (S) was significantly depressed (down to $9.25 \%$ ) compared to the control sample (C1), for which the dry matter content was $13.34 \%$ (Fig. 1). During the regeneration following the chill stress period ( $\mathrm{S}+\mathrm{R}$ sample), the dry matter concentration in roots increased to $11.92 \%$. The highest dry matter content in roots of

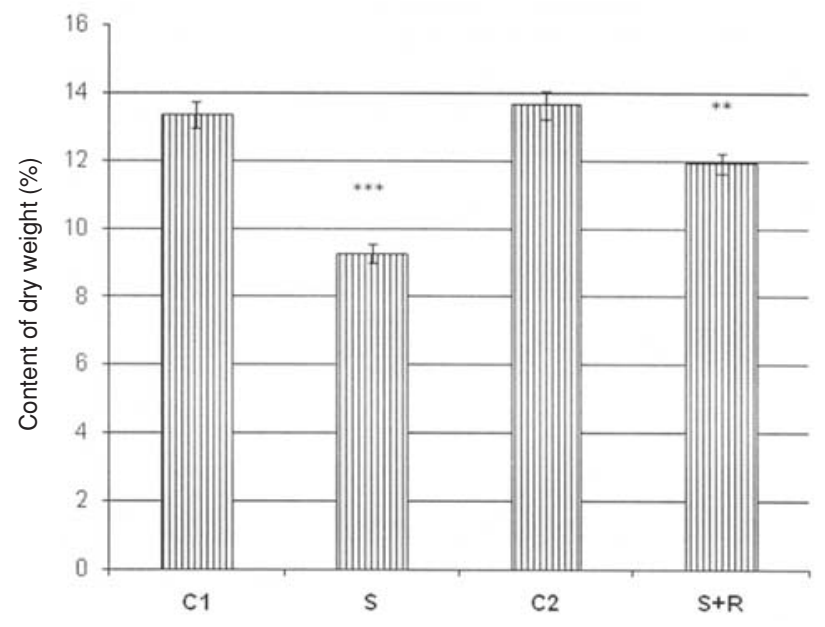

Fig. 1. Content of dry matter in roots of Vitis vinifera in control sample $\mathrm{C} 1$, in the sample subjected to chill stress (S), in control sample C2 and in the sample subjected to recovery after chill stress $(S+R)$. The experimental conditions are explained in Table 1 . The vertical lines mark standard deviation $(n=4)$. The asterisks designate significant differences (according to t-Student significance test) for dependent samples at $p<0.01$ $(* *)$, at $p<0.001(* * *)$. 


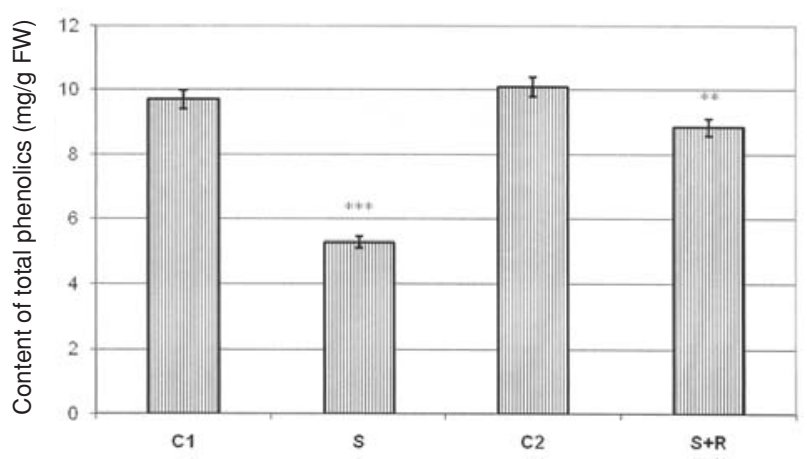

Fig. 2. Content of total phenolic compounds in roots of Vitis vinifera in control sample $\mathrm{C} 1$, in the sample subjected to chill stress (S), in control sample $\mathrm{C} 2$ and in the sample subjected to recovery after chill stress $(\mathrm{S}+\mathrm{R})$. The experimental conditions are explained in Table 1. The vertical lines mark standard deviation $(n=4)$. The asterisks designate significant differences (according to t-Student significance test) for dependent samples at $p<0.01(* *)$, at $p<0.001(* * *) ; \mathrm{FW}-$ fresh weight.

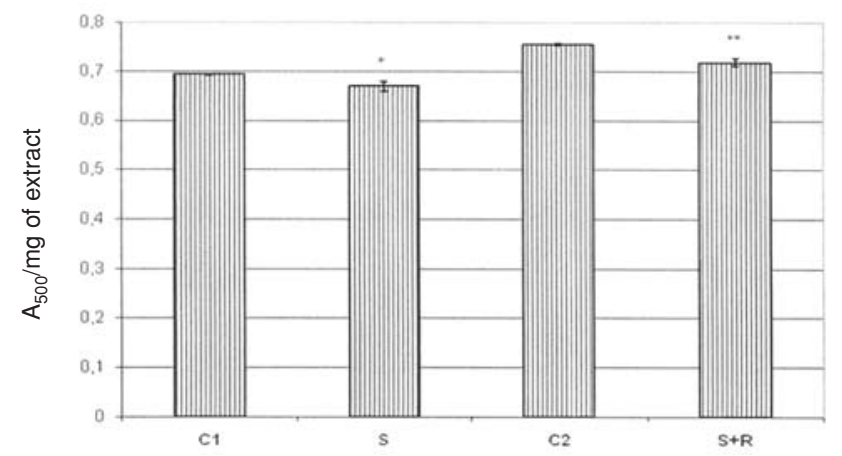

Fig. 3. Content of tannins in roots of Vitis vinifera determined by the Vanillin Assay method in control sample $\mathrm{C} 1$, in the sample subjected to chill stress $(\mathrm{S})$, in control sample $\mathrm{C} 2$ and in the sample subjected to recovery after chill stress $(\mathrm{S}+\mathrm{R})$. The experimental conditions are explained in Table 1 . The vertical lines mark standard deviation $(n=4)$. The asterisks designate significant differences (according to t-Student significance test) for dependent samples at $p<0.05(*)$, at $p<0.01(* *)$.

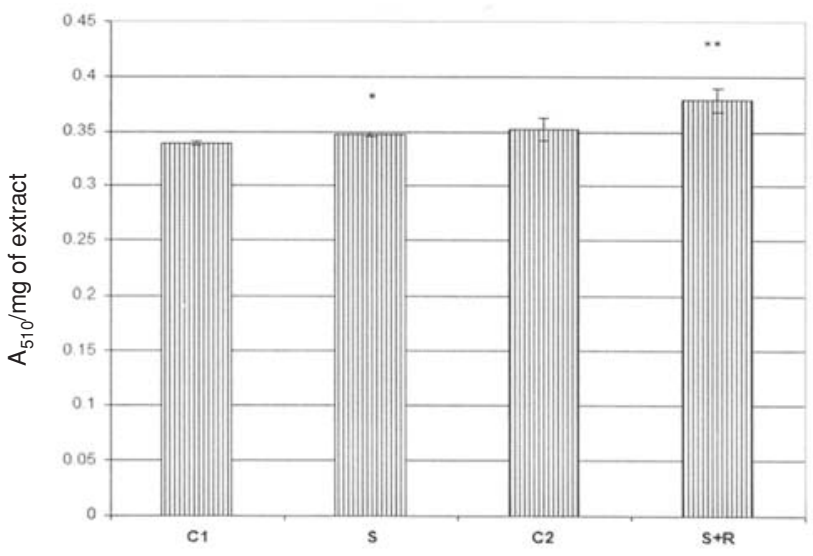

Fig. 4. Content of tannins in roots of Vitis vinifera determined by the BSA method in control sample $\mathrm{C} 1$, in the sample subjected to chill stress (S), in control sample $\mathrm{C} 2$ and in the sample subjected to recovery after chill stress $(\mathrm{S}+\mathrm{R})$. The experimental conditions are explained in Table 1. The vertical lines mark standard deviation $(n=4)$. The asterisks designate significant differences (according to t-Student significance test) for dependent samples at $\mathrm{p}<0.05(*)$, at $p<0.01(* *)$.

grapevine seedlings was determined in sample $\mathrm{C} 2$ $(13,64 \%)$.

\section{Content of phenolic compounds}

Analysis of the results shows that the total phenolics in grapevine roots after chill stress (S) are significantly lower according to several calculations $(339.44 \mathrm{mg} / \mathrm{g}$ of the extract, $56.91 \mathrm{mg} / \mathrm{g}$ of the dry matter, $5.27 \mathrm{mg} / \mathrm{g}$ of the fresh matter) versus the control sample (C1) (respectively $459.12 \mathrm{mg} / \mathrm{g}$ extract, $73.14 \mathrm{mg} / \mathrm{g}$ dry matter, 9.71 $\mathrm{mg} / \mathrm{g}$ fresh matter). Figure 2 comprises only the results recalculated per $g$ fresh matter of roots. In the sample regenerated after the chill stress period $(\mathrm{S}+\mathrm{R})$, a significant increase in the phenolic compounds has been found out $(8.85$ $\mathrm{mg} / \mathrm{g}$ fresh matter) compared to the sample which underwent chill stress only (S) $(5.27 \mathrm{mg} / \mathrm{g}$ fresh matter). The highest total content of phenolics was found in sample $\mathrm{C} 2$ (10.11 mg/g fresh matter) (Fig. 2).

\section{Content of tannins}

The content of tannins in grapevine roots has been tested using the Vanillin Assay and the BSA Precipitation Method. Vanillin Assay detects presence of condensed tannins. A significantly lower concentration of phenolic compounds has been determined in the sample subjected to chill stress (S), where it reached 0.67 , versus control sample $\mathrm{C} 1$, in which the absorbance was $0.69 \mathrm{~A}_{500} / \mathrm{mg}$ of the extract. In the sample which underwent recovery after chill stress $(\mathrm{S}+\mathrm{R})$, the content of condensed tannins increased (0.72 $\mathrm{A}_{500} / \mathrm{mg}$ extract), although the highest level of these tannins occurred in sample $\mathrm{C} 2\left(0.75 \mathrm{~A}_{500} / \mathrm{mg}\right.$ extract $)$. The data are presented in Figure 3.

The content of tannins determined with an aid of the BSA Precipitation Method is shown in Figure 4. This method serves for detection of concentrations of both condensed and hydrolysing tannins. The results indicate a significant increase in condensed and hydrolysing tannins in the sample subjected to chill stress $-\mathrm{S}\left(0.36 \mathrm{~A}_{510} / \mathrm{mg}\right.$ extract $)$ compared to control sample $\mathrm{C} 1\left(0.34 \mathrm{~A}_{510} / \mathrm{mg}\right.$ extract $)$. Both types of tannins were also found out to increase significantly during the recovery process after the chill stress $(\mathrm{S}+\mathrm{R})$, where the absorbance reading at $510 \mathrm{~nm}$ was 0.38 . The concentration of these compounds in sample $\mathrm{C} 2(0.35$ $\mathrm{A}_{510} / \mathrm{mg}$ extract) was similar to that in sample $\mathrm{S}$.

\section{Content of phenolic acids}

The assays performed on extracts from grapevine roots demonstrated that they contained $p$-coumaric, ferulic and caffeic acids. All these phenolic acids appeared in the roots as ester-bound compounds. Neither free forms of these acids nor glycoside-bound ones have been detected. Among the analysed samples (Figs 5-7), p-coumaric acid had the highest concentration (from 4.46 do $6.28 \mu \mathrm{g} / \mathrm{g}$ fresh root matter), followed by ferulic acid (from 1.68 to 2.65 $\mu \mathrm{g} / \mathrm{g}$ fresh matter), and caffeic acid (from 0.87 to 1.55 $\mu \mathrm{g} / \mathrm{g}$ fresh matter).

It has been demonstrated that the content of $p$-coumaric acid in the sample subjected to chill stress (S) fell down significantly $(4.46 \mu \mathrm{g} / \mathrm{g}$ fresh matter of roots) compared to control sample C1 (5.74 $\mu \mathrm{g} / \mathrm{g}$ fresh matter). It has also been found that the content of this acid increased significantly after recovery following the chill stress treatment $(S+R)-$ $5.64 \mu \mathrm{g} / \mathrm{g}$ fresh matter (Fig. 5).

The concentration of ferulic acid in grapevine roots was nearly three-fold lower that that of $p$-coumaric acid descri- 


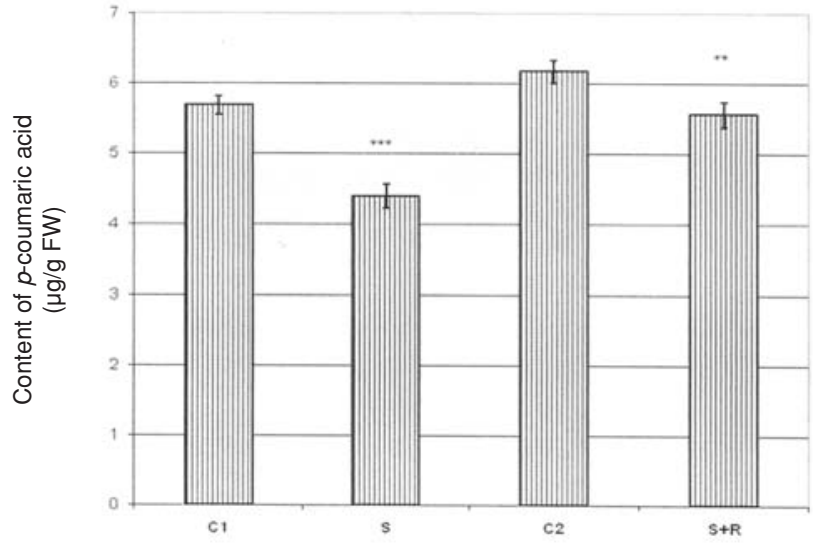

Fig. 5. Content of ester-bound form of $p$-coumaric acid in roots of Vitis vinifera in control sample $\mathrm{C} 1$, in the sample subjected to chill stress (S), in control sample $\mathrm{C} 2$ and in the sample subjected to recovery after chill stress $(\mathrm{S}+\mathrm{R})$. The experimental conditions are explained in Table 1. The vertical lines mark standard deviation $(n=4)$. The asterisks designate significant differences (according to t-Student significance test) for dependent samples at $p<0.01(* *)$, at $p<0.001(* * *) ; \mathrm{FW}-$ fresh weight.

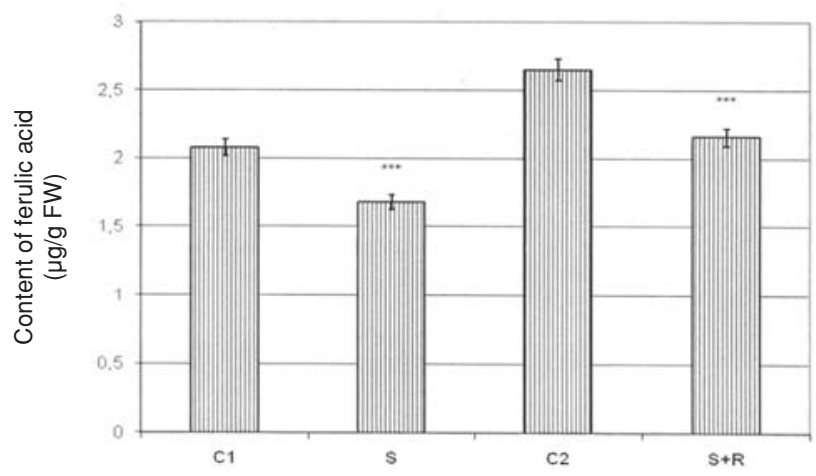

Fig. 6. Content of ester-bound form of ferulic acid in roots of Vitis vinife$r a$ in control sample $\mathrm{C} 1$, in the sample subjected to chill stress (S), in control sample $\mathrm{C} 2$ and in the sample subjected to recovery after chill stress $(\mathrm{S}+\mathrm{R})$. The experimental conditions are explained in Table 1. The vertical lines mark standard deviation $(n=4)$. The asterisks designate significant differences (according to t-Student significance test) for dependent samples at $p<0.001(* * *) ; \mathrm{FW}-$ fresh weight.

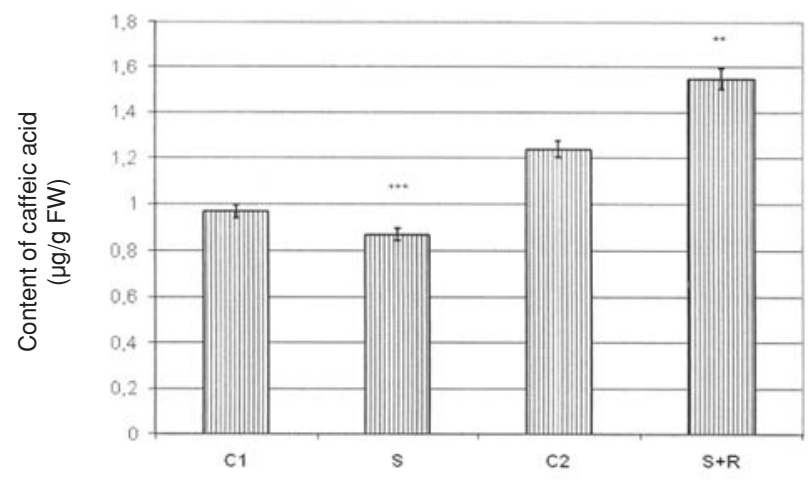

Fig. 7. Content of ester-bound form of caffeic acid in roots of Vitis vinife$r a$ in control sample $\mathrm{C} 1$, in the sample subjected to chill stress (S), in control sample $\mathrm{C} 2$ and in the sample subjected to recovery after chill stress $(\mathrm{S}+\mathrm{R})$. The experimental conditions are explained in Table 1. The vertical lines mark standard deviation $(n=4)$. The asterisks designate significant differences (according to t-Student significance test) for dependent samples at $p<0.01(* *)$, at $p<0.001(* * *) ; \mathrm{FW}-$ fresh weight.

bed above (Figs 5 and 6). Analogously to $p$-coumaric acid, however, the concentration of ferulic acid in the sample subjected chill stress (S) $(1.68 \mu \mathrm{g} / \mathrm{g}$ fresh matter) was signi- ficantly lower than in the control sample $(\mathrm{C} 1)-2.08$ $\mu \mathrm{g} / \mathrm{g}$ fresh matter. Significant differences were also observed when the sample which had undergone recovery after chill stress $(\mathrm{S}+\mathrm{R})(2.16 \mu \mathrm{g} / \mathrm{g}$ fresh matter) was compared to the sample which had been subjected to chill stress only (S), which indicates that ester-bound ferulic acid accumulates in roots during the recovery process (Fig. 6).

Among the phenolic acids identified in roots of grapevine Vitis vinifera, cv. Himrod, caffeic acid occurred in the lowest concentration. It has been demonstrated that it declined significantly, as expressed per root fresh matter, in the sample subjected to chill stress $(\mathrm{S})-0.87 \mu \mathrm{g}$, relative to the control sample $(\mathrm{C} 1)-0.97 \mu \mathrm{g} / \mathrm{g}$ fresh matter. Similarly to the results obtained for the other two phenolic acids, discussed earlier, the concentration of caffeic acid has been noticed to increase in roots during the recovery of plants after chill stress - sample $\mathrm{S}+\mathrm{R}(1.55 \mu \mathrm{g} / \mathrm{g}$ fresh matter). The content of caffeic acid in sample C2 was 1.24 $\mu \mathrm{g} / \mathrm{g}$ fresh matter and was between the values obtained for samples S and S+R (Fig. 7).

\section{The DPPH' free radical scavenging activity of extracts}

Fresh solution of DPPH• (2,2-diphenyl-1-picrylhydrazyl) free radical is purple in colour and reaches maximum absorbance at wavelength $517 \mathrm{~nm}$. The colour of the solution resulting from the presence of free radical disappears under the effect of antioxidative compounds, which extinguish DPPH'. When a free radical is bound to an antioxidant, a colourless product appears. In consequence, the solution becomes colourless and its absorbance is lower. The results of our assays are presented in Figure 8. Extracts of all the samples demonstrated DPPH ${ }^{\bullet}$ free radical scavenging activity, which suggests that they all contained antioxidants. The highest antioxidative activity was revealed by extracts characterised by the highest concentration of extract per $\mathrm{mg} / \mathrm{sample}$.

The weakest antioxidative activity was found for the extract obtained from grapevine roots subjected to chill stress $(\mathrm{S})$. At the highest extract concentration $(0.04$ $\mathrm{mg} / \mathrm{sample}$ ) the absorbance was 0.58 at $517 \mathrm{~nm}$ wavelength. This result indicates a significantly lower antioxidative activity versus the control sample (C1), for which the absorbance recorded at an identical extract concentration

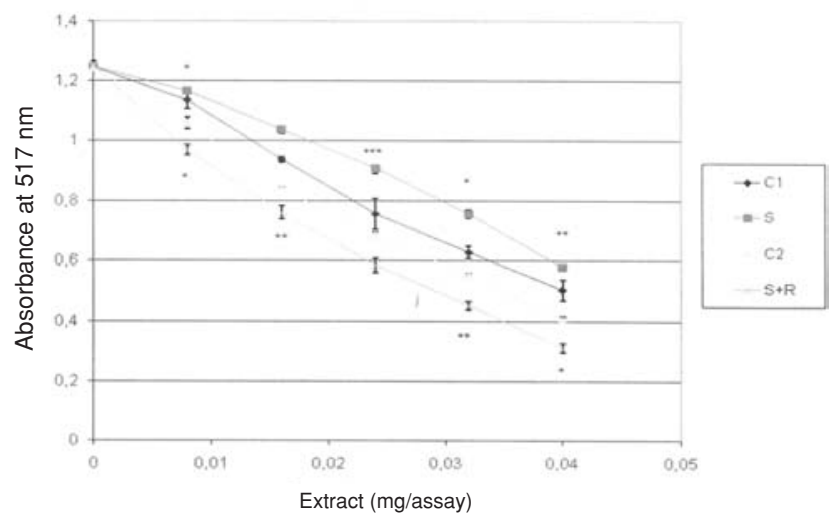

Fig. 8. DPPH free radical scavenging activity of extracts from grapevine roots in control sample $\mathrm{C} 1$, in the sample subjected to chill stress $(\mathrm{S})$, in control sample $\mathrm{C} 2$ and in the sample subjected to recovery after chill stress $(\mathrm{S}+\mathrm{R})$. The experimental conditions are explained in Table 1. The vertical lines mark standard deviation $(n=4)$. The asterisks designate significant differences (according to t-Student significance test) for dependent samples at $p<0.05(*)$, at $p<0.01(* *)$, at $p<0.001$ (***). 


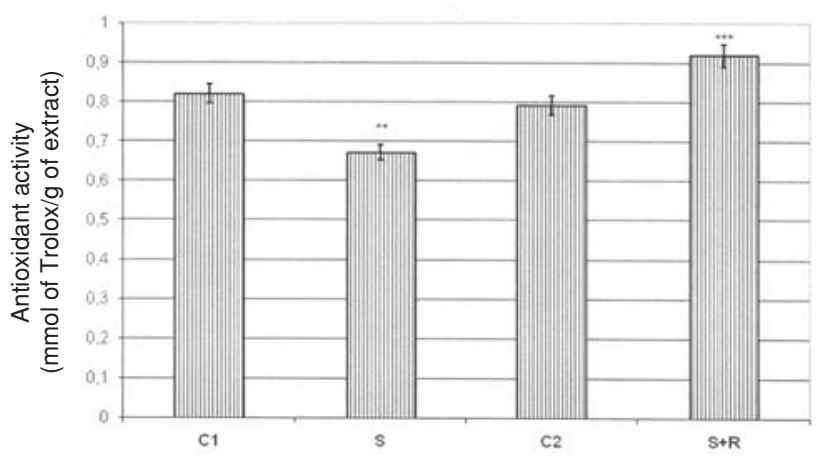

Fig. 9. $\mathrm{ABTS}^{+}$free cation radical scavenging activity of extracts from grapevine roots in control sample $\mathrm{C} 1$, in the sample subjected to chill stress (S), in control sample $\mathrm{C} 2$ and in the sample subjected to recovery after chill stress $(\mathrm{S}+\mathrm{R})$. The experimental conditions are explained in Table 1 . The vertical lines mark standard deviation $(n=4)$. The asterisks designate significant differences (according to t-Student significance test) for dependent samples at $p<0.01(* *)$, at $p<0.001(* * *)$.

was 0.51 . The highest capacity to scavenge $\mathrm{DPPH}^{\bullet}$ free radical was determined for an extract from roots which underwent recovery after chill stress $(\mathrm{S}+\mathrm{R})$. Its absorbance (at $517 \mathrm{~nm}$ ) for the highest extract concentration was 0.31 . The $\mathrm{DPPH}^{*}$ free radical scavenging activity of the control sample $\mathrm{C} 2$ was intermediate between the ones determined for samples $\mathrm{S}+\mathrm{R}$ and $\mathrm{S}$. The absorbance of the sample $\mathrm{C} 2$ at the highest extract concentration was 0.41 .

\section{The ABTS ${ }^{+\bullet}$ cation radical scavenging activity of extracts}

The ABTS ${ }^{+\bullet}$ - 2,2-Azino-bis (3-etylbenzothiazoline-6-sulfonic acid) cation radical scavenging activity is illustrated in Figure 9. The results showing the antioxidative activity of the extracts have been presented as Trolox equivalents. A colour solution of $\mathrm{ABTS}^{+\bullet}$ free cation radical becomes colourless when a root extract has been added to it. The rate at which the solution loses its colour depends on the amount of added extract and its free radical scavenging activity.

The results confirm that all the analysed samples were able to scavenge $\mathrm{ABTS}^{+\bullet}$ free cation radical. Analogously to the tests on $\mathrm{DPPH}^{*}$ free radical scavenging activity, discussed above, the sample subjected to chill stress (S) showed a significantly lower free radical scavenging activity $0.67 \mathrm{mmol}$ Trolox/g extract, when compared to the control sample $(\mathrm{C} 1)-0.82 \mathrm{mmol}$ Trolox/g extract. Similarly to the results reported above (on $\mathrm{DPPH}^{\cdot}$ free radical), $\mathrm{ABTS}^{+\cdot}$ free cation radical was most efficiently scavenged by extract obtained from the sample which recovered after chill stress $(\mathrm{S}+\mathrm{R})-0.92 \mathrm{mmol}$ Trolox/g extract. In both experiments, the values of scavenging activity for this sample $(\mathrm{S}+\mathrm{R})$ were significantly higher than those obtained for the sample subjected to chill stress (S). This suggests that a recovery period after chill stress could greatly enhance synthesis of antioxidative compounds.

\section{Reducing power of the extracts}

The results of the experiments on reducing power of the extracts are presented in Figure 10. Under the influence of the reducing power of the extracts, $\mathrm{Fe}^{3+}$ ions were reduced to $\mathrm{Fe}^{2+}$ and the colour of the reagent mixture changed from yellow to various tints of blue and green. The content of reduced $\mathrm{Fe}^{2+}$ ions was measured via determination of the

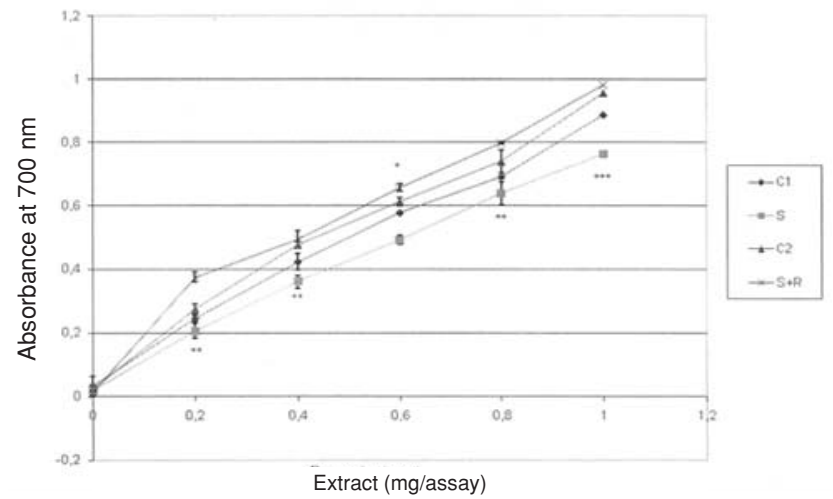

Fig. 10. Reducing power of extracts from grapevine roots in control sample $\mathrm{C} 1$, in the sample subjected to chill stress $(\mathrm{S})$, in control sample $\mathrm{C} 2$ and in the sample subjected to recovery after chill stress $(\mathrm{S}+\mathrm{R})$. The experimental conditions are explained in Table 1 . The vertical lines mark standard deviation $(n=4)$. The asterisks designate significant differences (according to t-Student significance test) for dependent samples at $p<$ $0.05(*)$, at $p<0.01(* *)$, at $p<0.001(* * *)$.

amount of Prussian blue in the extract. This was achieved by measuring absorbance at a wavelength of $700 \mathrm{~nm}$.

All the tested extracts had reducing power. The highest quantity of reducing compounds, among all the analysed extracts, was found in the sample which recovered after chill stress $(\mathrm{S}+\mathrm{R})$. At the extract concentration of 1 $\mathrm{mg} / \mathrm{sample}$, absorbance read at $700 \mathrm{~nm}$ wavelength was 0.98 , which was significantly more than an analogous value attained for the sample which only underwent chill stress $(S)-0.76$. Noteworthy is the fact that the extracts from roots obtained from plants subjected to chill stress (S) were characterised by the weakest reducing power. It should also be added that at the concentration of extract equal $1 \mathrm{mg} / \mathrm{sample}$, values of absorbance (at $700 \mathrm{~nm}$ wavelength) for samples $\mathrm{C} 1$ and $\mathrm{C} 2$ were 0.89 and 0.96 , respectively. These results suggest that chill stress conditions significantly depress the content of reducing compounds in roots, whereas during the recovery period after chill stress such compounds are intensively synthesised in cells and tissues of grapevine roots.

\section{DISCUSSION}

Responses of plants to various environmental stresses are very complex. Initially, the growth and development of plants is reduced or inhibited, after which the cellular metabolism becomes adapted to the stress conditions and the growth of plants is resumed. The adaptation involves synthesis of new macromolecules and changes in expression of many genes (Thomashow 1994).

The chill stress caused significant decrease in the dry matter of grapevine roots relative to the control and its increase during the recovery process after the stress. Other research has also demonstrated the inhibition of elongation of soybean roots after the transfer of 3-d-old seedlings grown at 25 to $10^{\circ} \mathrm{C}$. After 4 -d cultivation at low temperature, the soybean roots were about two times shorter in comparison to the control $\left(25^{\circ} \mathrm{C}\right)$ (Janas et al. 2000).

In roots of seedlings subjected to chill stress the total phenolic compounds were significantly lower. Similar results had been obtained in earlier studies on the influence 
of other abiotic stresses on plants. For example, a study on Amur grape seeds showed that during 3-day seed germination test under osmotic stress $(-0.5 \mathrm{MPa})$, the content of total phenolics, tannins and phenolic acids declined as compared to the control (Weidner et al. 2007). Other experiments proved that cells of unripe rye grains reacted to water stress by lowering the level of total phenolic compounds, and especially the content of phenolic acids (Weidner et al. 2000). Rudikovskaya et al. (2008), who examined the effect of growth temperature on the composition of phenols in pea roots, concluded that low temperature $\left(8^{\circ} \mathrm{C}\right)$ did not affect essentially the total content of phenolic compounds, but reduced considerably the content of flavon during the initial growth period. It reduced the number of compounds in the extract as well as their content. However, it needs to be emphasised that environmental stresses often raise the accumulation of phenylopropanoids (Dixon and Paiva 1995; Solecka 1997; Janas et al. 2000). Such differences are most likely attributable to the fact that the studies involved different abiotic stresses and biological material (characterised by a great diversity of secondary metabolites). In addition, the stresses occurred at different intensity levels.

The extracts from grape roots have been found to contain three phenolic acids: $p$-coumaric, ferulic and caffeic. All these phenolic acids appeared in roots as ester-bound compounds. Phenolic acids in plants can be bound with different substances and for phenolic estrification, for example, cholate and malate were identified (Bouchereau et al. 1991; Linscheid et al. 1980). Besides, the concentration of free phenolic acids in plant tissues is strictly monitored due to their potential toxicity (Harborne 1980). Estrification of phenolic acids enables plant cells and tissues to avoid the negative effect of accumulation of these compounds and makes it possible to transport them to vacuoles (Dixon and Paiva 1995).

Another interesting fact is that the total content of phenlic compounds and all the phenolic acids determined in the plant material rose during the recovery period after chill stress. Ester forms of phenolic compounds determined in grapevine roots can be used as substrates for vacuolar peroxidase in the peroxidase/phenolic/ascorbate system, which protect cells against ROS accumulated in tissues during the stress period (Takahama 1992; Grob and Matile 1980).

To control the level of reactive oxygen species plant tissues contain several enzymes scavenging ROS such as superoxide dismutase (SOD), peroxidases and catalases and a network of low molecular mass antioxidants such as ascorbate, glutathione, phenolic compounds and tocopherols. The regeneration of active forms of the antioxidants requires many enzymes. Phenolic compounds, which belong to the mentioned system, possess an ideal structural chemistry for free radical scavenging activity, and they have been shown to be more effective antioxidants than tocopheroles and asscorbate (Blokhina et al. 2003).

Antioxidant and antiradical activity of grape extracts can be studies with many various methods (Amarowicz and Weidner 2009). In our previous studies we demonstrated that the content of total phenolics in seeds of $V$. californica and $V$. riparia was very similar and about twice as high as the level demonstrated in $V$. amurensis. Also, the antiradical properties of phenolic compounds and reducing power of the seed extracts of phenolic compounds of $V$. californi$c a$ and $V$. riparia were similar and much stronger that those of $V$. amurensis (Powałka et al. 2004). In some other studies, the seed extracts examined obtained from grape seeds germinated in optimal conditions, showed a high capacity for scavenging $\mathrm{DPPH}^{\bullet}$ free radical and a high reducing power. Nonetheless, in the case of extracts from seeds germinated under osmotic stress, this capacity was much weaker (Weidner et al. 2007). The results of the study presented in this paper include a positive correlation between the total content of phenolic compounds in the extracts and their antioxidant capacity. Good correlation was also determined in another study between the total phenolic compounds content and free radical scavenging activities of different grape extracts (Caillet et al. 2006; Weidner et al. 2007).

There is an increasing interest in alternative agricultural land uses in north and eastern Europe. One such alternative is viticulture (Gustafsson and Martensson 2005). However, the gravest obstacle to growing grapevine in this part of Europe is the cool climate. Many researchers suggest that tolerance of plants to abiotic stresses is correlated with an increase in the antioxidant potential (Seel et al. 1991; Smirnoff 1993; Kranner et al. 2002). Many phenolic compounds in plants poses antioxidant activity and may help to protect cells against the oxidative damage caused by free radicals. This study confirms that phenolic compounds can also play an important role in recovery processes after period chill stresses and could help plants to survive difficult conditions.

\section{LITERATURE CITED}

AMAROWICZ R., PISKUŁA M., HONKE J., RUDNICKA B., TROSZYŃSKA A., KOZŁOWSKA H. 1995. Extraction of phenolic compounds from lentil seeds (Lens culinaris) with various solvents. Pol. J. Food Nutr. Sci. 4/45: 53-62.

AMAROWICZ R., WEIDNER S. 2001. Content of phenolic acids in rye caryopses determined using DAD-HPLC method. Czech J. Food Sci. 19: 201-203.

AMAROWICZ R., WEIDNER S. 2009. Biological activity of grapevine phenolic compounds. In: K.A. Roubelakis-Angelakis (ed.), Grapevine Molecular Physiology and Biotechnology, $2^{\text {nd }}$, edn. Springer Science + Business Media B.V. DOI 10.1007/978-90-481-2305-6-14: 389-405.

AOAC. Official Methods of Analysis, 15th ed. Arlington, Virginia, USA, 1990.

BARTOSZ G. 1997. Oxidative stress in plants. Acta Physiol. Plant. 19: 47-64.

BLOKHINA O., VIROLAINEN E., FAGERSTEDT K.V. 2003. Antioxidants, oxidative damage and oxygen deprivation stress: a review. Ann. Bot. 91: 179-194.

BOUCHEREAU A., HAMELIN J., LAMOUR J., RENARD M., LARHER F. 1991. Distribution of sinapine and related compounds in seeds of Brassica and allied genera. Phytochemistry 30: 1873-1881.

CAILLET S., SALMIERI S., LACROIX M. 2006. Evaluation of free radical-scavenging properties of commercial grape phenol extracts by a fast colorimetric method. Food Chem. 95: 1-8.

CHOI Y., LEE S.M., CHUN J., LEE H.B., LEE J. 2006. Influence of heat treatment on the antioxidant activities and polyphenolic compounds of Shiitake (Lentinus edodes) mushroom. Food Chemistry 99: 381-387.

DIXON R.A., PAIVA N.L. 1995. Stress-induced phenylpropanoid metabolism. Plant Cell 7: 1085-1097.

GROB K., MATILE P. 1980. Compartmentation of ascorbic acid in vacuoles of horseradish root cells. Note on vacuolar peroxidase. Z. Pflanzenphysiol. 98: 235-243. 
GUSTAFSSON J.G., MARTENSSON A. 2005. Potential for extending Scandinavian wine cultivation. Acta Agric. Scandinavica. Section B - Soil and Plant Sci., 55: 82-97.

GUY C.L. 1990. Cold acclimation and freezing stress tolerance: role of protein metabolism. Annu. Rev. Plant Physiol. 41: 187-223.

HAGERMAN A., BUTLER L. 1978. Protein precipitation method for quantitative determination of tannins. J. Agric. Food Chem. 26: 809-811.

HARBORNE J.B. 1980. Plant phenolics. In: Bell E.A., Charlwood B.V. (eds), Encyclopaedia of Plant Physiology Series 8. Pp 329-402.

JANAS K.M., CVIKROVA M., PAŁAGIEWICZ A., EDER J. 2000. Alternations in phenylpropanoid content in soybean roots during low temperature acclimation. Plant Physiol. Biochem. 38: 587-593.

KIM Y.C., CHUNG S.K. 2002. Reactive oxygen radical species scavenging effects of Korean medicinal plant leaves. Food Sci. Biotech. 11: 407-411.

KMIEĆ B., DRYNDA R., WOŁOSZAŃSKI M. 2005. Molecular basis of plant response to low temperature. Biotechnologia 3: 184-200.

KRANNER I., BECKETT R.P., WORNIK S., ZORN M., PFEIFHOFER H.W. 2002. Revival of a resurrection plant correlates with its antioxidant status. Plant J. 31: 13-24.

KRYGER K., SOSULSKI F.W., HOGGE L. 1982. Free, esterified, and insoluble-bound phenolic acids. 1. Extraction and purification procedure. J. Agric. Food. Chem. 30: 330-334.

LEVITT J. 1980. Responses of plants to environmental stress. Vol. I: Chilling, freezing, and high temperature stresses. Academic Press, New York.

LINSCHEID M., WANDISCH D., STRACK D. 1980. The structures of sinapic acid esters and their metabolism in cotyledons of Raphanus sativus. Z. Naturforsch. 35C: 907-914.

NACZK M., SHAHIDI F. 1989. The effect of methanol-ammonia-water treatment on the content of phenolic acids of canola. Food Chem. 31: 15-164.

POWAŁKA A., WRÓBEL M., KARAMAĆ M., AMAROWICZ R., FRACZEK E., WEIDNER S. 2004. Extracts of phenolic compounds of three grape varietes - comparison of total phenolics and tannins content, their antiradical activity and reduction power. Grapevine: From Ecophysiology to Molecular Biology. Cost 858 Workshop, April 30-May 1. Monte Verita, Ascona, p. 29.
PRICE N.J., VAN SCOYOC S., BUTLER L.G. 1978. A critical evaluation of the vanillic reactions an assay for tannin in sorghum grain. J. Agric. Food Chem. 26: 1214-1218.

RE R., PELLEGRINI N., PROTEGGENTE A., PANNALA A., YANG M., RICE-EVANS C. 1999. Antioxidant activity applying an improved ABTS radical cation decolorization assay. Free Rad. Biol. Med. 26: 1231-1237,

RUDIKOVSKAYA E.G., FEDOROVA G.A., DUDAREVA L.V., MAKAROVA L.E., RUDIKOVSKII A.V. 2008. Effect of growth temperature on the composition of phenols in pea roots. Rus. J. Plant Physiol. 55: 712-715.

SEEL W.E., HENDRY G.A.F., ATHERTON N.M., LEE J.A. 1991. Radical formation and accumulation in vitro in desiccation tolerant and intolerant mosses. Free Rad. Res. Comm. 15: 133-141.

SMIRNOFF N. 1993.The role of active oxygen in the response of plants to water deficit and desiccation. New Phytol. 125: 27-58.

SOLECKA D. 1997. Role of phenylolopropanoid compounds in plant response to different stress factors. Acta Physiol. Plant. 19: 257-268.

TAKAHAMA U. 1992. Hydrogen peroxide scavenging system in mesophyll cells of Vicia faba. Phytochemistry 31: 1127-1133.

THOMASHOW M.F. 1994. Arabidopsis thalianaas as a model for studying mechanisms of plant cold tolerance. In: Meyerowitz E.M., Somerville C.R. (eds), Arabidopsis, pp. 807-834. Cold Spring Harbour, NY: Cold Spring Harbour Laboratory Press.

WEIDNER S., AMAROWICZ R., KARAMAĆ M., FRACZEK E. 2000. Changes in endogenous phenolic acids during development of Secale cereale caryopses and after dehydration treatment of unripe rye grains. Plant Physiol. Biochem. 38: 595-602.

WEIDNER S., KARAMAĆ M., AMAROWICZ R., SZYPULSKA E., GOŁGOWSKA A. 2007. Changes in composition of phenolic compounds and antioxidant properties of Vitis amurensis seeds germinated under osmotic stress. Acta Physiol. Plant. 29: 283-290.

YEN G.C., CHEN H.Y. 1995. Antioxidant activity of various tea extracts in relation to their antimutagenicity. J. Agric. Food Chem. 43: 27-32.

ZADERNOWSKI R., KOZŁOWSKA H. 1983. Phenolic acids in soybean and rapeseed flours. Lebensm. Wiss. Technol. 16: 110-114. 